If the plan were successful, other meteorological facts might be determined by passing a current through mechanical indicator's attached to each piece of apparatus.

Changes of temperature, electric conditions, and rainfall, might ultimately be brought within the scope of such a plan of telegraphic registration, and three or four floating observatories might be arranged at considerable distances apart.

The problem thus presented to the mechanician is the construction of apparatus such that in passing an electric current successively through indicators specially devised for each instrument, readings could be made and announced to all concerned.

By such means all coasts liable to be visited by progressive storins might have timely warning of danger.

The cost of such work would be very small in comparison with the saving of life and property concerned.

The Board of Trade waight be induced to offer a substantial reward for the most efficient models of such floating stations.

The essential feature of this proposal is, that new instruments should be devised as entirely different in form from those in use as the aneroid is from the old barometer.

There is no reason to doubt that whenever instruments are devised in which the passage of an electric current can be made through the indicators, it will be as easy to take readings of meteorological instruments at the distance of a thousand miles as when in sight, and with sufficient accuracy for the purposes in view.

A HutTon BURGESS

The Dissociation of Sal-Ammoniac-An Experiment

ALL chemists admit that when sal-ammoniac is volatilised the vapour consists, if not wholly, at least in great part, of hydrochloric acid and ammonia gases in the free state. But this fact, so far as I am aware, is very seldom, if ever, demonstrated ex. perimentally by teachers. The following modification of Pébal's original experiment renders this proof very easy and available for lecture purposes :-

The stem of a long clay tobacco-pipe is passed loosely through a couple of perforated corks fitted into the two extremities of a piece of ordinary combustion tubing about a foot long. The tube contains in the middle a small lump of sal-ammoniac, and

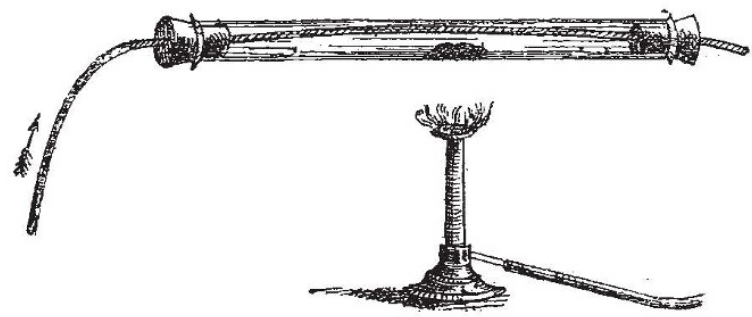

near each end a strip of blue litmus paper. When the middle of the tube is heated the vapour of the sal-ammoniac surrounds a portion of the pipe-stem. If, now, a rapid stream of air or any other indifferent gas is sent through the pipe, it is found to be strongly charged with ammonia, so that it answers freely to all the usual tests. At the same time the litmus papers contained in the glass tube become red owing to the accumulation of hydrochloric acid in the residue. This experiment, of course, depends upon the diffusion of the lighter ammonia through the clay more rapidly than the hydrochloric acid also present.

William A. Tilden

\section{The Sting of the Bee}

IN "The Origin of Species," p. 242, fourth edition, Mr. Darwin says, "If we look at the sting of the bee as having originally existed in a remote progenitor as a boring and serrated instrument, like that in so many members of the same great order, and which has been modified, but not perfected, for its present purpose, with the poison, originally adapted for some purpose such as to produce galls, subsequently intensified, we can, perhaps, understand how it is that the use of the sting should so often cause the insect's own death; for if, on the whole, the power of stinging be useful to the social community, it will fulfil all the requirements of natural selection, though $i_{t}$ may cause the death of some few members." In a lecture given as it happens, this day ten years ago, I ventured to suggest tha' bees may have derived advantage, not in spite of the fatal condition annexed to the use of their sting, but from that condition itself, since "it may have proved" expedient for a creature to be armed with a weapon capable of inspiring terror, yet so contrived, that its possessor should of necessity be peaceful towards its neighbours." It is very certain that many gentle-hearted human beings wage remorseless war upon wasps, who would never think of harming a bee or a bluebottle. On the other hand there are many mischievous persons ready enough to trifle with the feelings of a bluebottle, who keep at a respectful distance from a bee, simply because they know it possesses a certain power of revenge. In this way the sting is not, as your correspondent " R.A." is inclined to think, worse than useless to the individual bee, but an effective protection, albeit rather as a shield than a sword. What is needed for its efficacy is not so much intelligence in the bee as in those who would otherwise attack the bee, and though to the individual bee a single experience ending in its own death could be of no avail, yet the other animal, the wounded survivor in the fray, would have its understanding wonderfully quickened to the advantage of all bees it might meet in the future.

If, then, the bee is actually better off with its imperfect sting than it would be with one theoretically more perfect, it may be scarcely worth while to inquire whether a more effective weapon could or could not be developed on the principles of natural selection. But assuming that under given circumstances bees would derive advantage if the sterile workers had stings which they could use without sacrificing their own lives, the very statement of the hypothesis implies that a swarm, in which such workers were developed, would have an improved chance of surviving in the struggle for existence. Enemies would be more certainly vanquished; food would be more securely stored or in greater abundance; and thus the particular strain which had produced the improved variety would be more likely than others less favoured to be transmitted to future generations. The power of producing the better-armed warriors would be transmitted jus as the power of producing the worse-armed warriors is transmitted, neither in the one case nor the other through the warriors themselves.

Tunbridge Wells, February I

THOMAS R. R. STEBBING

\section{Fossil Forests and Silicified Trunks}

IN NATURE, vol, xix. p. 257, the discovery of fossil forests in the spring region of the Yellowstone River is referred to. I have visited the United States National Park, and its geysers, and observed exactly how silicified trunks in situ originate. All geologists suppose that this must have happened beneath water, and consequently Mr. Holmes supposes a constant alternation of land and sea throughout a long period of subsidence. My observations show the contrary, as silicified trunks originate only in air, never in water. The siliceous hot water of the geyser basins runs off periodically in another direction; if it comes to a forest, then all green leaves, all bark, and most of the branches fall off, but the trunks remain erect. Now the siliceons water rises by capillary attraction in the stem, but only on the outside of the trunk does the siliceous acid become solid by drying in the air . from the outside the silicification of the wood cells enters very slowly to the inner part; the trunks are mostly struck down by the wind before the inner part gets petrified, and then the inner part shows no ligneous structure, is only filled with foreign matter, or sometimes with other minerals, or it is hollow, for the inner wood decays. The white silicified wood is for a long time soft; lèss coherent than common wood, and if such trunks fall down into water, as I observed, they never get hard. Those white forests without leaves, bark, and branches, are not rare around the geysers. With my observations accord all characteristics of silicified trunks, i.e. such carbonaceous frunks excepted, that consist only of outfilled matter, stone kernels, for all real silicified trunks are barkless, leafless, branchless, often with inside hollow or partly filled, and always found along with common opal derived also from geysers.

Is silicification of trunks with well-preserved structure possible beneath water? No proof has yet been given. And further, would it be possible for stems, which are lighter than water, to remain in situ and erect by sinking under water? Scarcelyonly if previously silicified and heavy.

Besides, most statements of travellers on fossil forests relate to the tropics. I saw several on my voyage round the world, which consisted only of stens lying together.

Leipzig-Eutritzsch, January 28 